\title{
Is Human Life Absurd?
}

\author{
Billy Holmes ${ }^{1}$
}

Received: 27 April 2017 / Accepted: 6 May 2018 /

Published online: 31 May 2018

(C) The Author(s) 2018

\begin{abstract}
This essay examines whether or not absurdity is intrinsic to human life. It takes Camus' interpretation of 'The Absurd' as its conceptual starting point. It traces such thought back to Schopenhauer, whose work is then critically analysed. This analysis focuses primarily on happiness and meaning. This essay accepts some of Schopenhauer's premises, but rejects his conclusions. Instead, it considers Nietzsche's alternatives and the role of suffering in life. It posits that suffering may help people acquire meaning and escape absurdity. It then analyses the role of compassion in absurdity, in reference to Nietzsche's work and Buddhist teachings. Lastly, it examines absurdity in relation to death, rejecting the notion that death exacerbates absurdity. This paper understands absurdity to be a natural part of the human condition, as characterised by suffering, death and an absence of meaning. It concludes that although human life is absurd by nature, it need not remain so.
\end{abstract}

Keywords Absurd $\cdot$ Life $\cdot$ Meaning $\cdot$ Schopenhauer $\cdot$ Nietzsche $\cdot$ Death

This essay examines the notion of absurdity being intrinsic to human life. It takes Camus' interpretation of 'The Absurd' as its conceptual starting point. This essay traces such thought back to Schopenhauer, whose 'pain and boredom' thesis and subsequent call for asceticism are then critically analysed. It then considers Nietzsche's alternative solution to Schopenhauer's dilemma. Lastly, this essay analyses the role of compassion in absurdity. It does so in reference to Nietzsche's work and Buddhist teachings. It concludes that whilst human life is absurd by nature, it need not remain so, as we can project meaning onto life.

Absurdity seems to characterise human life. Here, absurdity is taken to mean the unresolvable tension between human aspirations for meaning and the universe's "unreasonable silence" on such matters (Camus and O'Brien 1991, p.28). In other words, the Absurd "arises because the world fails to meet our demands for meaning" (Nagel

\section{Billy Holmes}

1 Kotobuki Heights, Kochi, Japan 
1971, p.721). Furthermore, there seems to be no conceivable world "about which unsettlable doubts could not arise" (Nagel 1971, p.722). Thus, the Absurd is derived from "a collision within ourselves" (Nagel 1971, p.722). Therefore, absurdity appears intrinsic to the human condition, as characterised by suffering, death and an absence of meaning.

Such thought seems to stem from Schopenhauer. Schopenhauer posited: "there is always...a sense of emptiness prevalent" owed to the "misery and barrenness of our existence" (Schopenhauer and Saunders 2007, p.15). He concludes that life's ultimate constituents are pain and boredom, and we merely oscillate between these two states (Schopenhauer and Payne 2012, p.312). I shall thus consider Schopenhauer's work on absurdity in regard to meaning and happiness, here taken as counterparts to barrenness and misery.

Within this, I shall assume that meaning is distinct from happiness (Wolf 2012, p.74). I will do so because people seemingly think about life's possibilities in terms of either one of these concepts, or both. Insofar as we think about life solely in terms of happiness, we "neglect...meaningfulness" (Wolf 2012, p.96). This essay shall address both concepts, though it shall focus primarily on meaningfulness.

Within Schopenhauer's work, 'boredom' is understood as frustration. This arises from the satisfaction of desires: "If one...lacks objects of willing...deprived...[by] satisfaction...boredom comes over [one]" (2012, p.312). The pressure to will continues, but it can find no goal to latch on to. This "longing without a definite object" causes a "deadening languor" (Schopenhauer and Payne 2012, p.164). On the other hand, 'Pain' is construed as stress stemming from unsatisfied desires. Schopenhauer saw human life as a "constant transition from desire to satisfaction...[to] fresh desire" (2012, p.164). Thus, suffering is taken to be intrinsic to the human condition.

Schopenhauer's work concerned the balance between happiness and suffering. He posited that absurdity results from the latter vastly outweighing the former (Young 2003, p.34). This entails consideration of the "one truly serious philosophical problem...suicide (Camus and O'Brien 1991, p.3). Schopenhauer posits that the ultimate solution to the problem of life consists in death. But, he rejects suicide on the grounds that this constitutes escapism from suffering, rather than an attempt to acquire detached knowledge of it. However, he accepts the philosophical validity of death via asceticism - denial of the will (desire to act) - as this reduces the pain and boredom associated with living.

Schopenhauer assumes that "each individual act has a[n] end" (2012, p.165). Thus, pain and boredom are seemingly entailed solely by telic activities i.e. activities which come to an end. Here, frustration and stress appear related to the sense of distance between one and one's goal, as fulfilment is always in the future or the past (Setiya 2014, p.15). However, Schopenhauer's work appears unable to account for activities which lack definite ends (atelic). Schopenhauer also assumes that the satisfaction of a desire constitutes the desire's immediate elimination. This also appears problematic, as a range of desires are capable of being satisfied without being eliminated e.g. being a philosopher (Young 2003, p.42). Additionally, Schopenhauer's 'pendulum' exaggerates the brevity of happiness between the stress of striving to satisfy a desire and the frustration that follows its satisfaction. It also defies intuition. Although one may inevitably become bored after attaining a goal, there seems to be scope for enjoyment prior to this. 
Furthermore, the cost-benefit approach implicit within Schopenhauer's work appears problematic. He posits that "the finest part of life, its purest joy...is pure knowledge," but "higher intellectual powers make [people]... susceptible to much greater sufferings" (Schopenhauer and Payne 2012, p.314). Specifically, he says that such power "makes them feel lonely" (2012, p.314). Such thought seemingly parallels one's capacity for happiness, with that for pain. He also declares: "by its very nature and origin [the human being] is...destined to pain" (2012, p.312). Therefore, as suffering is deemed inevitable, one may seemingly justify risking 'greater suffering' as an attempt to gain greater 'joy'.

Such thought warrants consideration of Nietzsche, as he approaches the issue from Schopenhauer's perspective but draws a contrary conclusion. Nietzsche champions the "strong, bold, audacious soul" (2001, p.171). He posits that approaching life in this way entails the "happiness of Homer" i.e. the happiness of the man who invented the Gods for himself (Nietzsche et al. 2001, p.172). He does so in spite of this making one "more capable of suffering," as "one becomes ever more refined in pain" (Nietzsche et al. 2001, p.172). Thus, Nietzsche acknowledges the risk of pain but advocates courageousness.

Nietzsche ascribes pain a positive role in the 'heroic' project of 'stamping' meaning onto life. Within this, he says that human life is absurd with regard to the absence of God(s). But, he challenges the assumption that absurdity is necessarily entailed by human life. He posits that "Mankind is...to be surpassed" by "the Superman," who "shall be the meaning of the earth" (Nietzsche and Common 1885, p.7). Nietzsche parallels his notion of 'surpassing' with biological evolution: just as the ape serves as a "laughing-stock" for man, "so shall...man be to the Superman" (1885, p.7). Nietzsche envisions this 'surpassing' as epistemological evolution wherein, 'Superman' status is a way of thinking. This mode of thought allows one to 'stamp' meaning onto life. The 'Superman' takes the place of God(s). Homeric happiness thus ensues, due to man's having created this figure. By restricting human "conjecturing" to both its "creating will" and "the conceivable," everything is "transformed into the humanly conceivable" and the universe is "created" by humanity (Nietzsche and Common 1885, p.79). Therefore, absurdity, as entailed by the universe's "unreasonable silence," need not remain intrinsic to human life (Camus and O'Brien 1991, p.28).

Nietzsche's 'Superman' concept also seemingly averts the risks of stress and frustration associated with telic activities. This is due to it being a way of thinking, and thus lacking a definite end (atelic). One may satisfy the desire to become the 'Superman,' without entailing the elimination of that desire. Allowing one's life to be formed by a desire whose satisfaction does not entail its own extinction thus averts Schopenhauer's 'stress' or 'frustration' argument (Young 2003, p.43). Nietzsche's conclusion also seemingly aligns itself with the intent behind Schopenhauer's recommending asceticism: to reduce pain and boredom. Here, the pain of a 'mid-life crisis' may be prevented by "investing more deeply in atelic ends" e.g. striving for 'Superman' status (Setiya 2014, p.15). Nietzsche elucidates the nature of this process. Within this, the principle of "life as a means to knowledge" enables one to live and laugh "gaily" (Nietzsche et al. 2001, p.181). Consequently, one finds life "truer" and "more desirable" (Nietzsche et al. 2001, p.181). He challenges humankind to look directly at its inhered existential absurdity and continue to move 'heroically' into the future for the sense of power and joy that this gives. He posits that such actions can 
entail meaning and happiness, with existential laughter expressing this process of selfcreation. Nietzsche also draws on Schopenhauer's work instrumentally, by granting suffering a positive, creative role. According to Nietzsche, although "creating" is "the great salvation from suffering," it requires "suffering" for its initiation (Nietzsche and Common 1885, p.80). Through aiding the creation of the 'Superman,' suffering may serve as a means to meaning and happiness.

The notion of suffering leading to meaning and happiness may be further developed through reference to the individualising nature of suffering. Intuitively, suffering appears unique to each person (non-fungible). Realising the intrinsically alienating nature of this may facilitate individual thought. The notion of individuality is integral to Nietzsche's epistemological evolution, as he advises would-be 'Supermen' to "flee" orthodox thought and seek "solitude" (1885, p.48). Nietzsche's 'Superman' is understood as one who has transcended orthodox thought and willingly embraces hardship and isolation, for self-improvement. He is an affirmation of human potential capable of replacing 'God' through his ability to 'stamp' meaning onto life. Nietzsche condemns any who leave "regions where it is hard to live" as the "most despicable" people (Nietzsche and Common 1885, p.11). He posits that doing so reveals their incapacity for the pain required to strive for 'Superman' status, a capacity that he champions as 'heroic.' Suffering may allow us to escape absurdity.

Additionally, suffering may provide the grounds for compassion: an additional source of meaning and happiness. Like the pursuit of 'Superman' status, compassion can seemingly provide an endless supply of meaning and happiness, due to its atelic nature. Compassion actively binds us to life. It enables a greater appreciation of commonality and diversity, with meaning and happiness derived from helping others realise their potential i.e. becoming 'Supermen'. Compassion appears compatible with Nietzsche's positing: "making [others] joyful [is] the greatest of all joys" (Nietzsche and Hollingdale 1982, p.177). The process of becoming a 'Superman' seems high in internal meaning, due to its containing activities that are worthwhile for the subject (Bradley 2015, p.416). On the other hand, a life devoted to helping others seems high in external meaning (Bradley 2015, p.416). Thus, incorporating compassion into one's life may enable the fulfilment of both of these categories.

Compassion requires the 'Superman' mode of thought. Without this, one cannot seemingly help others attain this status. Also, in the absence of independent thought, one's actions may lack authenticity. If so, one cannot produce genuine compassion, in any form. This notion may adhere to Nietzsche's vision whereby, "the [universe] shall be created by you...your love, shall it become" (1885, p.79). Within this, self-love is an integral part of achieving 'Superman' status. This may enable compassion as one ought to "Love your neighbor as yourselves - but first be such as love themselves" (Nietzsche and Common 1885, p.164). He construes compassion as empathy aimed at enabling self-improvement: "If...you have a suffering friend, then be a resting-place for his suffering; like a hard bed...will you serve him best. ... [above] pity" (Nietzsche and Common 1885, pp.83-84). Acknowledging the absurdity of human life, in relation to pain, boredom and "unreasonable silence" may highlight the need for the "Superman' as its resolution (Camus and O'Brien 1991, p.29).

Alternatively, the reduction of pain and boredom may be confined to asceticism and life left devoid of meaning and happiness. Here, Schopenhauer's rejection of "purest joy" (pure knowledge) appears premised, in part, on its entailing loneliness 
(Schopenhauer and Payne 2012, p.314). However, such feelings do not appear confined to "higher intellectual powers," as one cannot be anything other than alone in one's mind (Schopenhauer and Payne 2012, p.314). Loneliness also need not result from such 'joy,' as one may help others attain 'Superman' status after reaching it oneself. Such thought may align itself to Nietzsche's 'Will to Power' wherein, we should think individually whilst reaching beyond ourselves. This urges us to risk suffering to 'expand ourselves' and take humans beyond their current situation i.e. to a new ('Super') way of being.

Furthermore, whilst the active nature of compassion seemingly conflicts with asceticism's passivity, it still accords with Schopenhauer's intent: to reduce pain and boredom. Departing from his radically subjective perspective enables a more holistic framing of pain and boredom. This accounts for individuals' impact upon the pain and boredom of others. Each person may potentially reduce the overall amount of pain and boredom by a more significant degree than can be achieved via asceticism. Compassion appears increasingly compatible with Schopenhauer's work upon consideration of its Buddhist underpinnings. Schopenhauer drew upon major Buddhist doctrines: 'life is suffering'; suffering stems from our 'craving' (willing); and one may cease to suffer if one ceases to will. (Young 2003, p.39). Hence, compassion - an integral part of Buddhism - appears compatible with Schopenhauer's philosophy.

This section shall analyse absurdity in relation to death. Does death exacerbate absurdity? Death seems to harm the 'value' of our projects. This appears to exacerbate absurdity somewhat. However, "to the extent that the value of our projects lies beyond our individual interests," their worth is "protected to that extent against death" (Sigrist 2015 , p.84). Thus, compassion may greatly undermine the extent of harm inflicted by death (Sigrist 2015, p.84). Additionally, 'value' appears distinct from meaning. Here, 'value' is understood as independent of one's own existence. Hence, it departs from the concept of the Absurd. Sigrist also posits that whilst death "can harm the welfare" of life, it cannot harm its meaning. Therefore, death has no impact upon absurdity i.e. the absence of meaning (2015, p.94). Alternatively, death may reduce absurdity and/or enable humankind to escape from it. Here, "the certain prospect of death could introduce into every life a precious, sweet-smelling drop of levity" (Nietzsche and Hollingdale 1996, p.390). With humour playing a crucial part in Nietzsche's philosophy, such 'levity' may be both desirable in itself, and as a means to 'Superman' status. Furthermore, he posits that finitude is "not riddle enough" to scare away human love or limit human wisdom. Awareness of this is considered to be "a humanly good" that allows us to understand the universe in human terms. (Nietzsche and Common 1885, pp.180-181). This notion of life being worthwhile by virtue of its being comprehensible seemingly accords to his willing everything to be "transformed into the humanly conceivable" (Nietzsche and Common 1885, p.79). Immortality would thus be undesirable insofar as it is unknown and/or unintelligible. Hence, the finiteness of life limits absurdity by allowing us to 'stamp' meaning onto it.

Death appears similarly required for the kind of meaning associated with the aforementioned atelic activities. Compassion i.e. empathy enabling self-improvement, may become untenable as, given infinite time, mankind may, in theory, reach a stage where improvement is no longer possible. This appears similarly applicable to 'Superman' status, as one may cease the process of 'becoming'. In sum, we exist as agents capable of recognising, valuing and striving for meaning because we are mortal (Sigrist 
2015, p.99). Therefore, death reduces absurdity as it allows us to invest meaningfully in these atelic ends.

In conclusion, human life is naturally absurd, due to its being characterised by suffering, death and an absence of meaning. However, it may become otherwise as one may 'stamp' meaning onto life through compassion and striving for 'Superman' status. Doing so enables, and may provide, happiness. Until one endeavours for such, acknowledgement of life being constituted by pain and boredom seemingly warrants Schopenhauer's ascetic conclusion. This has been found wanting. Whilst asceticism may reduce pain and boredom, it may do so to a lesser extent than compassion. Schopenhauer's asceticism appears unreasonably ego-centric and unappealing, in part due to its precluding any possible happiness.

\section{Compliance with Ethical Standards}

Conflict of Interest On behalf of all authors, the corresponding author states that there is no conflict of interest.

Open Access This article is distributed under the terms of the Creative Commons Attribution 4.0 International License (http://creativecommons.org/licenses/by/4.0/), which permits unrestricted use, distribution, and reproduction in any medium, provided you give appropriate credit to the original author(s) and the source, provide a link to the Creative Commons license, and indicate if changes were made.

\section{References}

Bradley, B. (2015). Existential terror. The Journal of Ethics, 19(3-4), 409-418. https://doi.org/10.1007 /s10892-015-9204-7.

Camus, A., \& O'Brien, J. (1991). The myth of Sisyphus, and other essays. New York: Vintage Books.

Nagel, T. (1971). The absurd. The Journal of Philosophy, 68(20), 716-727. https://doi.org/10.2307/2024942.

Nietzsche, F., \& Common, T. (1885). Thus Spake Zarathustra. New York: Feedbooks.

Nietzsche, F., \& Hollingdale, R. (1982). Daybreak. Cambridge [Cambridgeshire]: Cambridge University Press.

Nietzsche, F., \& Hollingdale, R. (1996). Human, all too human. Cambridge: Cambridge University Press.

Nietzsche, F., Williams, B., Nauckhoff, J., \& Del Caro, A. (2001). The gay science. Cambridge: Cambridge University Press.

Schopenhauer, A., \& Payne, E. F. J. (2012). The world as will and representation, volume 1. New York: Courier Corporation.

Schopenhauer, A., \& Saunders, T. B. (2007). Parerga and Paralipomena: A collection of philosophical essays. New York: Cosimo.

Setiya, K. (2014). The midlife crisis. Philosophers' Imprint, 14(31).

Sigrist, M. J. (2015). Death and the meaning of life. Philosophical Papers, 44(1), 83-102. https://doi. org/10.1080/05568641.2015.1014541.

Wolf, S. (2012). Meaning in life and why it matters. Princeton: Princeton University Press.

Young, J. (2003). The death of god and the meaning of life. New York: Taylor \& Francis. 